\title{
Synthesis of new functionalized Calix[4]arene modified silica resin for the adsorption of metal ions: Equilibrium, thermodynamic and kinetic modeling studies
}

\author{
Nida Shams Jalbani ${ }^{a}$, Amber R. Solangi ${ }^{a, *}$, Shahabuddin Memon ${ }^{a}$, Ranjhan Junejo ${ }^{a}$, Asif Ali Bhatti ${ }^{b}$, \\ Mehmet Lütfi Yola ${ }^{c}$, Muhammad Tawalbeh ${ }^{\mathrm{d}}$, Hassan Karimi-Maleh ${ }^{\mathrm{e}, \mathrm{f}, *}$ \\ ${ }^{a}$ National Centre of Excellence in Analytical Chemistry, University of Sindh Jamshoro 76080, Pakistan \\ ${ }^{\mathrm{b}}$ Department of Chemistry, Government College University Hyderabad, Hyderabad 71000, Pakistan \\ ${ }^{\mathrm{c}}$ Hasan Kalyoncu University, Faculty of Health Sciences, Department of Nutrition and Dietetics, Gaziantep, Turkey \\ ${ }^{\mathrm{d}}$ Sustainable and Renewable Energy Engineering, University of Sharjah, P.O. Box 27272, Sharjah, United Arab Emirates \\ ${ }^{\mathrm{e}}$ School of Resources and Environment, University of Electronic Science and Technology of China, P.O. Box 611731, Xiyuan Ave, Chengdu, PR China \\ ${ }^{\mathrm{f}}$ Department of Chemical Engineering, Quchan University of Technology, Quchan, Iran
}

\section{A R T I C L E I N F O}

\section{Article history:}

Received 19 March 2021

Revised 26 May 2021

Accepted 14 June 2021

Available online 17 June 2021

\section{Keywords:}

Functionalized Calix[4] arene

Silica resins

Metal ions adsorption

Thermodynamics investigation

Kinetic modeling studies

\begin{abstract}
A B S T R A C T
In this study, a new efficient resin-based material has been synthesized through the surface modification of silica by functionalized calix[4]arene and applied for the adsorption of metal ions from aqueous media. The synthesis of functionalized calix[4]arene modified silica (FCMS) resin was characterized by FTIR, CHNS, BET surface area, SEM analyses. The FCMS resin has high thermal and chemical stabilities that were checked by the thermogravimetric analysis and various acidic/basic conditions. The efficiency of the FCMS resin was checked by performing a set of batch experiments under optimized parameters such as concentration of the metal solution, $\mathrm{pH}$, resin dosage, time, temperature, and competitive adsorption in mixed solutions. The results showed that better adsorption has been achieved at pH 7, with $25 \mathrm{mg}$ adsorbent dosage and 10 min contact time. The equilibrium kinetic study showed that the metal adsorption follows the pseudo 2nd order kinetic model with quite high coefficients of determination values $\left(R^{2}>0.99\right)$. The experimental data have been validated by applying three adsorption isotherm models and the results revealed that the Freundlich isotherm model $\left(R^{2}>0.99\right)$ was the best fit for the adsorption of $\mathrm{Cu}^{2+}, \mathrm{Pb}^{2+}$, and $\mathrm{Cd}^{2+}$ ions. However, the sorption energy calculated from the D-R isotherm model for $\mathrm{Cu}^{2+}, \mathrm{Pb}^{2+}$, and $\mathrm{Cd}^{2+}$ ions suggested that an ion-exchange mechanism is involved on the surface of the FCMS resin. The thermodynamic data demonstrated that the reaction is spontaneous and endothermic. The FCMS resin was also applied on real wastewater samples and the results demonstrated that the resin has a good ability to treat metal-contaminated wastewater.
\end{abstract}

(c) 2021 Elsevier B.V. All rights reserved.

\section{Introduction}

Water pollution by toxic materials such as drugs, metal ions is poisonous for humans and aquatic life [1-6]. These metal ions are non-degradable and their entrance into the body causes dermal irritation and bacterial and viral infections [7]. It is well known that heavy metals have no nutritional value, however, their excess harms the human organs by altering, removing, impairing the enzyme function [8-11]. Heavy metal action in the human body is like an enzyme mimics. These metals bind targeted molecules

\footnotetext{
* Corresponding authors.

E-mail addresses: ambersolangi@gmail.com (A.R. Solangi), hassan@uestc.edu.cn (H. Karimi-Maleh)
}

such as DNA or enzyme's binding sites, remove their essential minerals and inhibit their proper functions. Such harmful activities are the main reason for kidney damage, lungs tissue destruction, and bladder diseases [12-14]. Therefore, it is necessary to remove or degradation of these toxicants from water sources.

Typically, different methods are used to remove heavy metals from water such as the coagulation method, online dialysis, ion exchange chromatographic process, chemical precipitation, adsorption, electrolytic process, solvent extraction, and reverse osmosis [15-21]. Among these techniques, adsorption is efficient, low cost and environmentally friendly technique [22-26]. In adsorption, different natural and synthetic adsorbents are used [27-29]. Examples of natural adsorbents are lignin, cellulose, chitosan, etc., while synthetic adsorbents include crown ethers, 
cyclodextrin, and many polymeric-based resins. These adsorbents have a wide $\mathrm{pH}$ range, fast kinetic, high loading capacity, excellent selectivity, strong affinity, and adequate reusability [27,30,31]. In general, adsorbents could be classified into organic-based and inorganic-based. Organic-based can be further classified into natural organic sorbents or synthetic polymers. Examples of inorganicbased adsorbents are zeolites, clays, $\mathrm{SiO}_{2}, \mathrm{Al}_{2} \mathrm{O}_{3}$, and some other oxides [32].

Immobilization of organic moieties onto organic or inorganic polymeric matrices is used to introduce certain functional groups for selective adsorption of analytes. After immobilization, the selectivity of the modified solid adsorbent towards certain ionic species is attributed to many common factors, such as the size and chemical structure of the organic moieties used for the surface modification, type of functional group, and their activity in the presence of other interfering groups. However, the selective adsorption of specific analyte among the interfering ions is a challenging task that requires the search for a material that exhibits a good affinity to bind selectively with that analyte or ionic species. Therefore, the combinations of organic functional groups onto inorganic polymer may thus be advisable [32].

Among different inorganic polymers, silica gel is commonly used as an adsorbent because it does not swell or strain under environmental conditions and has good chemical, thermal as well mechanical strength [32]. The silanol groups present onto silica can be easily modified with organic moieties. Thus, modification of silica surface with organic groups have been performed to obtain the solid-phase adsorbent material which has a higher selectivity and better thermal and chemically stabilities [33]. The functional groups can be attached either chemical immobilization or physical attachment. In chemical immobilization, the new chemical bond is formed in between inorganic polymer and organic moieties [34]. Previously, different functional groups were chemically immobilized onto silica surface but nowadays, the third generation supramolecular compounds known as calixarenes are also used as functional materials. Calixarenes are cyclic oligomers of phenol units and have well-known attractive and excellent ionophores due to the unlimited derivatization. Calixarenes consists of the upper aromatic and lower phenol oxygen rims. Both upper and lower rims can be functionalized to bind with neutral molecules, anions, and cations. The calixarenes functionalized by different moieties such as amines, amides, carbonyls, nitriles, and other suitable moieties that can bind to metal ions, anions, and neutral molecules [35,36]. Therefore, the chemical immobilization of calix[4] arene-based frameworks onto silica enhances the reusability, selectivity, loading, or adsorption capacity of an adsorbent [37]. Previously, different studies have been carried out on calix[n] arene-based adsorbents, such as diethanolamine-calix[4]arene attached to silica and applied for the treatment of DB-38 contaminated-water [38]. Another study was performed for the adsorptive removal of toxic-metal ions such as $\mathrm{Cd}, \mathrm{Pb}$, and $\mathrm{Hg}$ from water samples using amine-functionalized calix[4]arene-based silica resin [39]. Similarly, the piperidine attached silica resin has been synthesized and used as an adsorbent for $\mathrm{Cu}$ and $\mathrm{Pb}$ metal ions from aqueous solutions [40]. Another derivative of calix[4] arene layered double hydroxide $\left(\mathrm{SC} 4 \mathrm{~A}-\mathrm{NO}_{3}-\mathrm{LDH}\right)$ has been reported and applied for the selective removal of metal ions from aqueous solutions [41].

Herein, the calix[4]arene has been functionalized at the upper rim using pyrrolidine moiety. After that, the functionalized calix [4]arene has been chemically immobilized onto the silica surface. This functionalized calix[4]arene modified silica (FCMS) resin is applied for the adsorption of metal ions from water samples. The new FCMS resin has good thermal and chemical stability, adequate reusability, and high adsorption capacities for $\mathrm{Cu}, \mathrm{Cd}$, and $\mathrm{Pb}$ metal ions in wastewater samples.

\section{Experimental work}

\subsection{Materials}

The chemicals used in the synthesis were analytical grade and procured from Merck Company (Table S1) while the silica gel (230-400 mesh size) was purchase from Fisher Chemical ${ }^{\mathrm{TM}}$. The elemental analyzer (model Flash EA1112, 20090-Rodano, Milan Italy) was used for elemental analyses of synthesized compounds. The Thermo Nicollet 5700 FTIR spectrometer was used to characterize the materials. The surface of the resin has been characterized by SEM (JSM-6380). The BET surface area was analyzed using Quanta chrome $^{\circledR}$ ASiQwin ${ }^{\mathrm{TM}}$ surface area analyzer, the analysis gas was nitrogen, and the outgas time was $90 \mathrm{~min}$. The metal ion concentrations were determined by atomic absorption (Spectra Varian A.A. 400 spectrophotometer). The weight loss determination calculations were performed under air in a platinum crucible on a Perkin Elmer Diamond TG/DTA, at a heating rate of $10^{\circ} \mathrm{C} \mathrm{min}^{-1}$. All metal nitrate solutions were prepared in deionized water.

\subsection{Synthesis}

Compounds (1-4) shown in (scheme-1) have been prepared according to the published method after modification [42-44] and characterized by FTIR, SEM, BET, and TGA techniques.

\subsubsection{Synthesis of FCMS resin}

In $6 \mathrm{~g}$ of crystalline solid silica, $50 \mathrm{~mL}$ of $0.1 \mathrm{M} \mathrm{HCl}$ solution was added then washed and dried for $2 \mathrm{~h}$ at $130^{\circ} \mathrm{C}$. In dry silica, $50 \mathrm{~mL}$ of $0.1 \mathrm{M}$ solution of $\mathrm{SiCl}_{4}$ and $4.3 \mathrm{~mL}$ of triethylamine were added. Resultant a cloudy solution has been formed that was kept for $8 \mathrm{~h}$. After that, the remaining solvent from the solution was removed by suction and white powder solid silica was obtained. This powder silica has been added into $100 \mathrm{~mL}$ of chloroform followed by the addition of $1.6 \mathrm{~g}$ of $p$-pyrrolidinomethylcalix[4]arene and $2 \mathrm{~mL}$ of triethylamine (Fig. 1). The reaction was refluxed continue and confirmed by FTIR spectroscopy. After confirmation, the product was washed with chloroform, water, methanol, and chloroform to remove other impurities. The amount of attached $p$ pyrrolidinomethylcalix[4]arene onto silica was checked by gravimetric analysis and it was found to be $0.467 \times 10^{-4} \mathrm{mmol} / \mathrm{g}$.

\subsection{Adsorption process}

The adsorption was performed by adding $25 \mathrm{mg}$ of the FCMS resin to $10 \mathrm{~mL}$ of metal nitrate solutions with concentrations ranging from $1 \times 10^{-4}$ to $1 \times 10^{-8}(\mathrm{~mol} / \mathrm{L})$ at $25^{\circ} \mathrm{C}$. The influence of $\mathrm{pH}$ on adsorption percentage was studied ranging from acidic-basic. After adsorption, the remaining concentrations were determined through atomic absorption spectrometric measurements, and adsorbed amounts of metal ions were calculated using Eqs. (1) and (2):

$\%$ Adsorption $=\frac{C_{i}-C_{f}}{C_{i}} \times 100$

$Q m=(C e-C) \times \frac{V}{m}$

$Q_{m}=\left(C_{e}-C\right) \times \frac{V}{m}$

where $C_{i}$ and $C_{f}(\mathrm{~mol} / \mathrm{L})$ is the initial and final concentrations of metal ions, respectively, $Q_{m}$ is the adsorption capacity (mol/g) of FCMS resin, $C_{e}$ and $C(\mathrm{~mol} / \mathrm{L})$ are the equilibrium and final concentrations, respectively, $m$ is the mass of FCMS resin (mg) and $V$ is the 


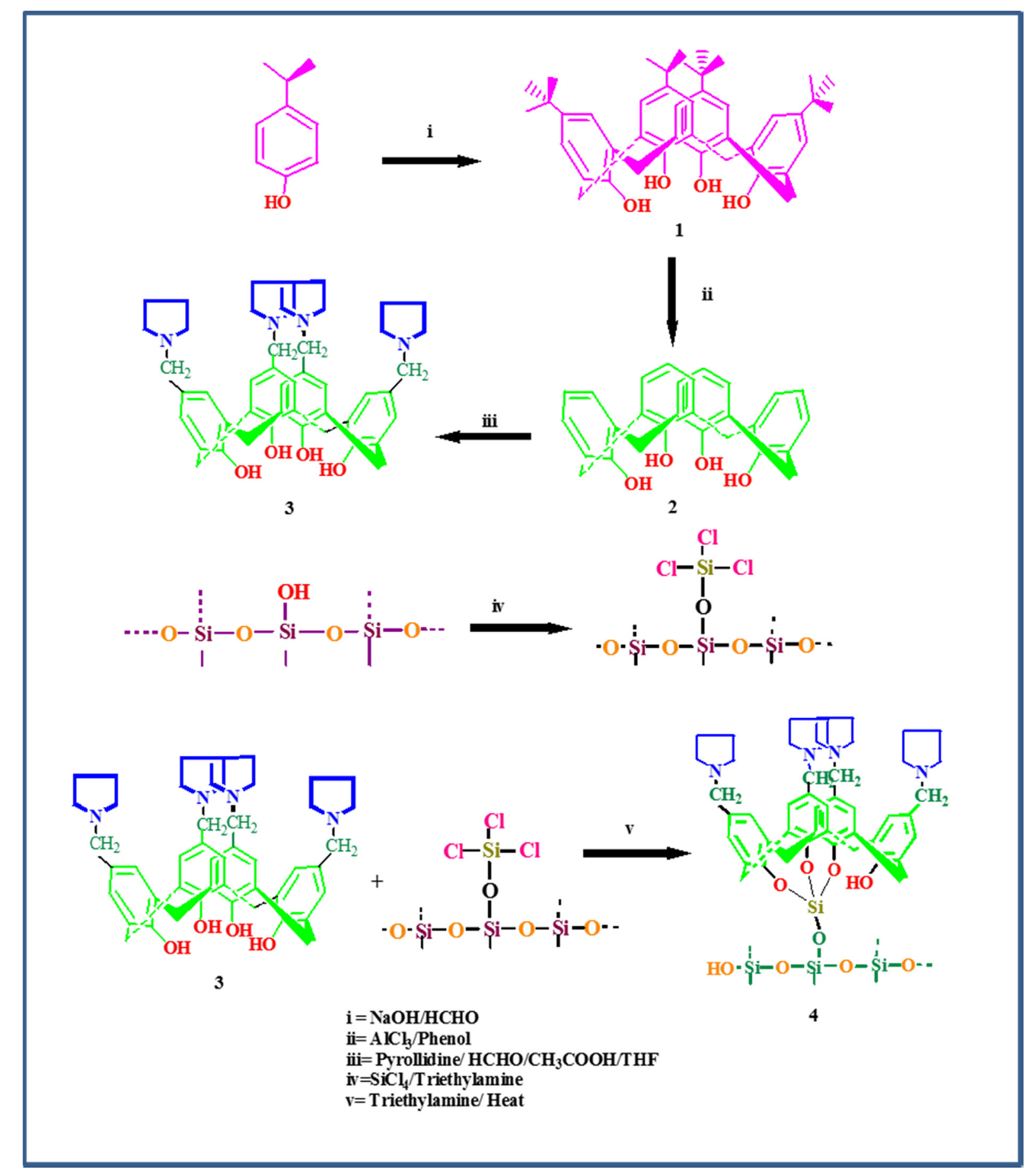

Fig. 1. Synthesis route of FCMS resin.

volume of metal solution (L). The reported results are the average of three duplicates.

\section{Results and discussion}

\subsection{FTIR study}

The FCMS resin has been synthesized using $p$-pyrrolidinome thylcalix[4]arene immobilized onto a silica surface. The immobilization of $p$-pyrrolidinomethylcalix[4] arene onto the silica surface was analyzed using FTIR spectroscopy as shown in Fig. 2. In Fig. 2, spectrum (a) belongs to p-pyrrolidinomethylcalix[4]arene, which shows peaks at $3505,3015,1750,1535$, and $1207 \mathrm{~cm}^{-1}$ for $\mathrm{OH}$, $\mathrm{CH}_{2}, \mathrm{C}=\mathrm{C}, \mathrm{C}-\mathrm{O}$, and $\mathrm{C}-\mathrm{N}$ stretching frequencies, respectively. Spectrum (b) is for free silica, which shows peaks at $3534 \mathrm{~cm}^{-1}$ for Si$\mathrm{OH}$ stretching, at $1718 \mathrm{~cm}^{-1}$ for Si-O stretching, and at $1195 \mathrm{~cm}^{-1}$ for the $\mathrm{OH}$ bending frequency. Spectrum (c) is for FCMS resin which shows some additional new characteristic peaks at 3470 , $3117,1733,1557$, and $1108 \mathrm{~cm}^{-1}$ for $\mathrm{OH}, \mathrm{C}-\mathrm{H}, \mathrm{C}=\mathrm{C}, \mathrm{C}-\mathrm{N}$, and Si$\mathrm{O}$ groups, respectively. The new additional peaks observed after the immobilization of $p$-pyrrolidinomethylcalix[4]arene onto the free silica confirms that the FCMS resin has been formed. 


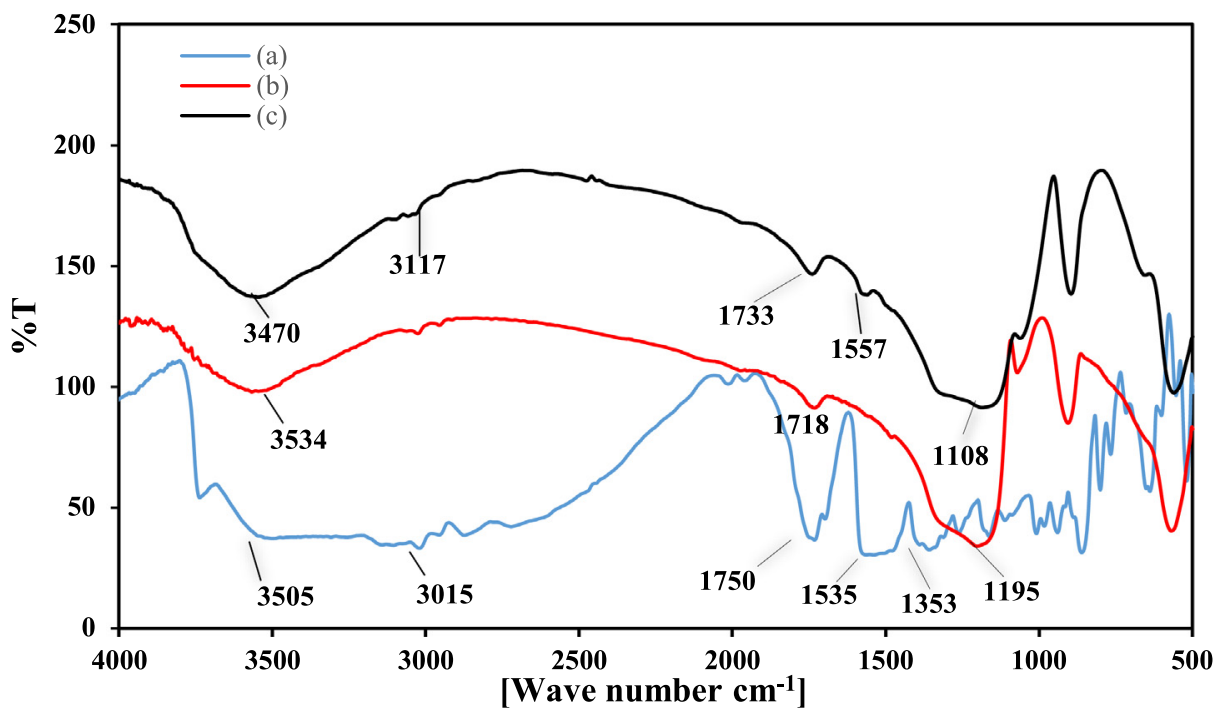

Fig. 2. FT-IR Spectra (a) of p-pyrrolidinomethylcalix[4]arene (b) free silica and (c) FCMS resin.

\subsection{Scanning electron microscopic (SEM) study}

The SEM images of free silica and immobilized silica are shown in Fig. 3. It is clear from comparing both images that image (a) is for free silica which has smooth crystalline surface morphology while image (b) is for FCMS resin which looks rough and amorphous after immobilization of $p$-pyrrolidinomethylcalix[4]arene onto the free silica particles. This roughness that was observed in image (b) indicates that the p-pyrrolidinomethylcalix[4]arene has been immobilized onto the silica surface successfully. Previously, such types of adsorbents were prepared and characterized by the SEM technique. Examples are p-tert-butylcalix[8]arene [45] and

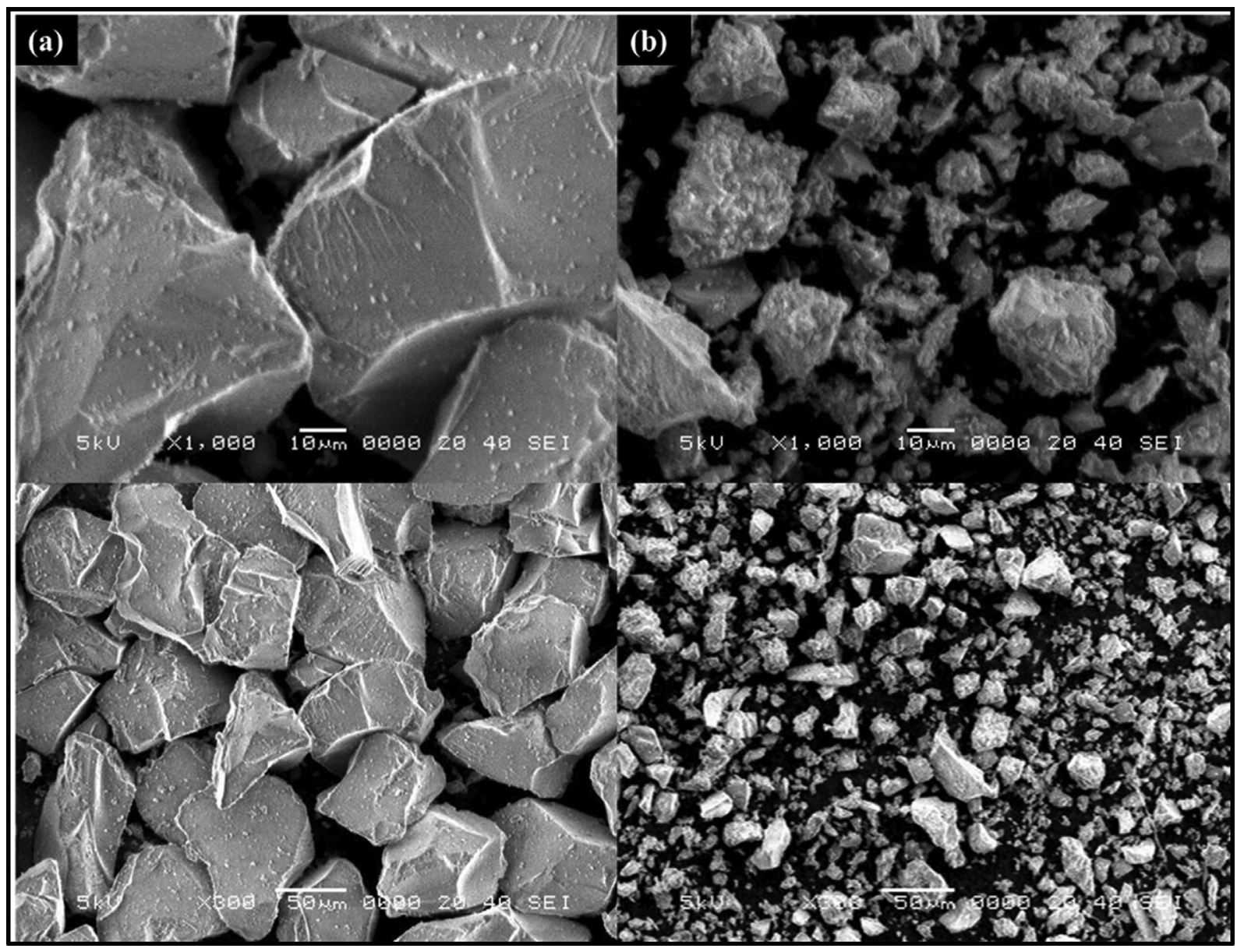

Fig. 3. The scanning electron microscopic analysis of free silica (a) and immobilized silica (b). 
piperdinomethylcalix[4]arene immobilized on silica and applied for the removal of azo dyes and metal ions removal from water, respectively.

\subsection{Elemental analysis}

The immobilization of $p$-pyrrolidinomethylcalix[4]arene onto silica surface has been analyzed by the CHNS technique. The results given in Table 1 show that the free silica has no \% C, and \% N. However, the FCMS resin formed after immobilization of $p$-pyrrolidino methylcalix[4]arene onto the silica surface has $2.89 \% \mathrm{C}, 0.89 \% \mathrm{~N}$, and $2.18 \% \mathrm{H}$ which indicates the successful immobilization.

\subsection{TGA analysis}

The thermal stability of FCMS resin in an inert atmosphere was examined using TGA analysis as shown in Fig. S1. The TGA analysis shows that the thermal degradation of FCMS takes place in 2 steps. The 1 st step is from 40 to $190{ }^{\circ} \mathrm{C}$ with a rapid weight loss area where the adsorbed water molecules were removed. After that, slow weight loss occurred between $190^{\circ} \mathrm{C}$ and $700{ }^{\circ} \mathrm{C}$ and that was due to the dehydration of $(\mathrm{Si}-\mathrm{OH})$ groups. The main losses were observed at $400{ }^{\circ} \mathrm{C}$ and that was due to the combustion of p-pyrrolidnomethylcalix[4]arene moieties. TGA analysis was used previously in the literature to investigate the thermal stability of different resins such as 4-tert-butyl-calix[6] arene chemicallyimmobilized onto silica [46] and calix[4]arene-based modified Amberlite-resin [47].

\subsection{Stability of FCMS resin in acidic and basic solution}

The stability of FCMS resin has been checked in acidic and basic solutions ( $\mathrm{pH} 1$ to 9 ). The chemical stability of functional moieties on the resin was analyzed before and after reactions with acid and base using FTIR spectroscopy as depicted in Fig. S2 and elemental analysis techniques as shown in Table S2. It was clear that there is no change in the material after $32 \mathrm{~h}$ of contact.

\subsection{Surface properties}

The BET surface area $\left(\mathrm{S}_{\mathrm{BET}}\right)$, pore diameter, and pore volume for the FCMS resin have been measured using Barrett-Joyner-Halenda $(\mathrm{BJH})$ method and nitrogen adsorption - desorption isotherms evident in Fig. S3. As revealed in Table 2, the amount of the p-pyrroli dinomethylcalix[4]arene immobilized on the polymeric silica backbone has characteristics surface area and pore volume. Furthermore, the adsorption-desorption isotherms shown in Fig. S3 are type IV.

\section{Optimization of adsorption parameters}

\subsection{Influence of $\mathrm{pH}$}

The influence of $\mathrm{pH}$ on the adsorption percentage of $\mathrm{Cu}^{2+}, \mathrm{Cd}^{2+}$, and $\mathrm{Pb}^{2+}$ has been analysed in the range from 1 to 11 as demonstrated in Fig. 4. It has been noticed that the adsorption percentages of metal ions at low $\mathrm{pH}$ values were not significant and that is due mainly to amine ligands being fully protonated. However,

Table 1

Elemental Analysis of free and immobilized silica.

\begin{tabular}{llll}
\hline Sample & $\% \mathrm{C}$ & $\% \mathrm{~N}$ & $\% \mathrm{H}$ \\
\hline Free Silica $\left(\mathrm{SiO}_{2}\right)$ & $0.00 \%$ & $0.00 \%$ & $0.34 \%$ \\
Immobilized Silica (FCMS resin) & $2.89 \%$ & $0.89 \%$ & $2.18 \%$ \\
\hline
\end{tabular}

Table 2

The surface properties of FCMS resin.

\begin{tabular}{clll}
\hline Adsorbent & $\begin{array}{l}\text { Specific surface } \mathrm{S}_{\mathrm{BET}}\left(\mathrm{m}^{2} /\right. \\
\mathrm{g})\end{array}$ & $\begin{array}{l}\text { Pore volume }\left(\mathrm{cm}^{3} /\right. \\
\mathrm{g})\end{array}$ & $\begin{array}{l}\text { Pore } \\
\text { Radius }\end{array}$ \\
\hline $\begin{array}{c}\text { FCMS } \\
\text { resin }\end{array}$ & 218.681 & 0.951 & $96.429 \AA$ \\
\hline
\end{tabular}

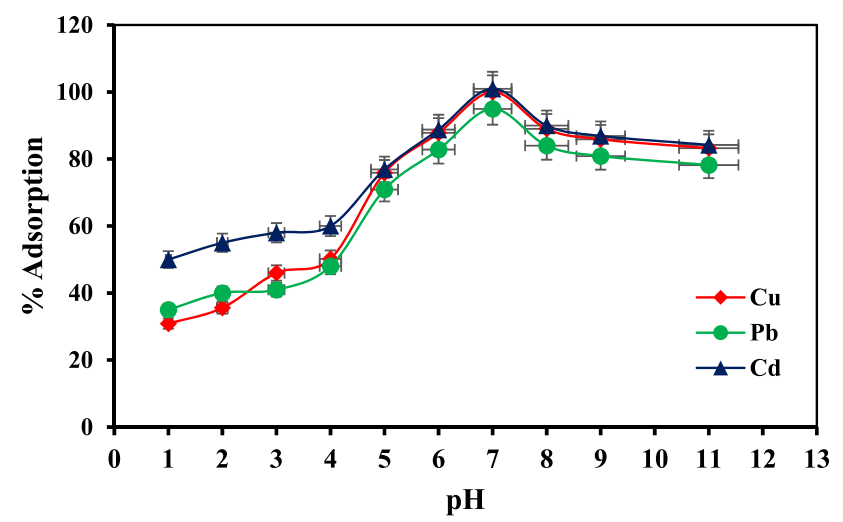

Fig. 4. The effect $\mathrm{pH}$ on adsorption of $\mathrm{Cu}^{2+}, \mathrm{Cd}^{2+}$ and $\mathrm{Pb}^{2+}$ metal ions ( $10 \mathrm{~mL}$ of metal nitrates solution, $1 \times 10^{-4} \mathrm{~mol} / \mathrm{L}$ concentration at $25^{\circ} \mathrm{C}$ ).

after increasing the $\mathrm{pH}$, adsorption percentages were increased and the protonation reduced which improved the adsorption where adsorption percentages reached the maximum between $\mathrm{pH} 6$ to 7. Increasing the $\mathrm{pH}$ further led to a decrease of adsorption percentages and that is due to the hydrolysis reaction of metal ions (leading to $\mathrm{M}(\mathrm{OH})^{+}$and $\mathrm{M}(\mathrm{OH})_{2}$ hydroxides). This hydrolysis reaction caused uncertainty between the amount of $\mathrm{M}^{2+}$ hydrolysed or adsorbed. Hence, all the experiments were performed at pH 7.

\subsection{Dosage effect}

The effect of the adsorbent dosage on the \% adsorption is a very crucial parameter to evaluate the quality of adsorbent materials. Hence, a graph has been plotted between \% adsorption versus the dosage of the FCMS resin as shown in Fig. 5. It is evident from Fig. 5 that the \% adsorption of $\mathrm{Cu}^{2+}, \mathrm{Pb}^{2+}$, and $\mathrm{Cd}^{2+}$ ions increases with the increase of the FCMS resin dosage from 5 to $25 \mathrm{mg} / \mathrm{L}$ and reaches around 99\%. This is due to the availability of more binding sites. Increasing the dose of the FCMS resin further has no significant effect on \% adsorption. Hence, the optimized dose of FCMS resin for the $\mathrm{Cu}^{2+}, \mathrm{Pb}^{2+}$, and $\mathrm{Cd}^{2+}$ removal is $25 \mathrm{mg} / \mathrm{L}$.

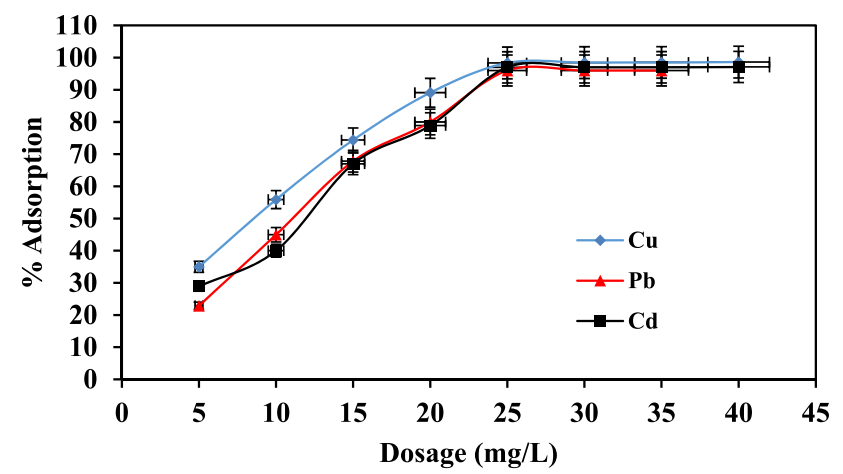

Fig. 5. Dosage effect of FCMS resin ( $10 \mathrm{~mL}$ of metal nitrate solution $1 \times 10^{-4} \mathrm{~mol} / \mathrm{L}$, 10 min contact time, pH 7 at $25^{\circ} \mathrm{C}$ ). 
Therefore, all other experiments have been performed using a $25 \mathrm{mg}$ dosage of the FCMS resin.

\subsection{Optimization of time and kinetic modeling}

The influence of the contact time on the adsorption of $\mathrm{Cu}^{2+}$, $\mathrm{Pb}^{2+}$, and $\mathrm{Cd}^{2+}$, by the FCMS resin was studied using the batch methodology. It is evident from Fig. 6 that the maximum \% adsorption was achieved after $10 \mathrm{~min}$. This is due to the fast external diffusion on the surface of FCMS resin. The functional moieties present in the resin surface are arranged in such a pattern that the accessibility of metal ions is not affected and faster interactions were observed in between the FCMS resin and metal ions. The adsorption of metal ions occurred in the order of $\mathrm{Cu}^{2+}>\mathrm{Cd}^{2+}>$ $\mathrm{Pb}^{2+}$ at the 10 min optimized time. This can be attributed to the ionic size, hydration energy, and binding constant values of metal complexes.

In light of the above equilibrium data, kinetic studies have been performed to identify the mechanism of the adsorption rate of metal ions using the pseudo 1st order (Eq. (3)) and pseudo 2nd order (Eq. (4)) models:

$\ln \left(q_{e}-q_{t}\right)=\ln q_{e}-k_{1} t$

$\frac{t}{q_{t}}=\left(\frac{t}{k_{2} q_{e}^{2}}\right)+\left(\frac{1}{q_{e}}\right)$

In the above Equations, $q_{e}$ and $q_{t}$ are the amounts in ( $\mathrm{mol} / \mathrm{g}$ ) adsorbed of metal ions at equilibrium and at time $t$, respectively, and $k_{1}$ and $k_{2}$ are the kinetic rate constants for the pseudo 1 st order and pseudo 2nd order models, respectively. Using Eq. (3) the equilibrium data were subjected to the pseudo 1 st order kinetic model and the experimental data were plotted between $\ln \left(q_{e}-q_{t}\right)$ vs. $t$ (min) as shown in Fig. 7 (a). The values of $q_{e}$ and $k_{1}$ reported in Table 3 have been obtained from the slope and intercept of the graph. Similarly, the pseudo 2nd order kinetic model (Eq. (4)) was applied to experimental data by plotting the graph between $t / q_{t}$ vs $t$ (min) as depicted in Fig. 7 (b) to determine the value of $q_{e}$ and $k_{2}$ as shown in Table 3. It is clear from Table 3 that the coefficient of determination $\left(R^{2}\right)$ values of the pseudo 2 nd order model were higher than 0.99 for the three investigated metal ions. These values were also significantly higher than the $R^{2}$ values for the pseudo 1 st order. Therefore, the adsorption of $\mathrm{Cu}^{2+}, \mathrm{Pb}^{2+}$, and $\mathrm{Cd}^{2+}$ by the FCMS resin follows the pseudo 2 nd order kinetic model quite well and the rate-limiting step is likely to be chemisorption. This involves valency forces by sharing or exchanging electrons between metal ions and the FCMS resin [48].

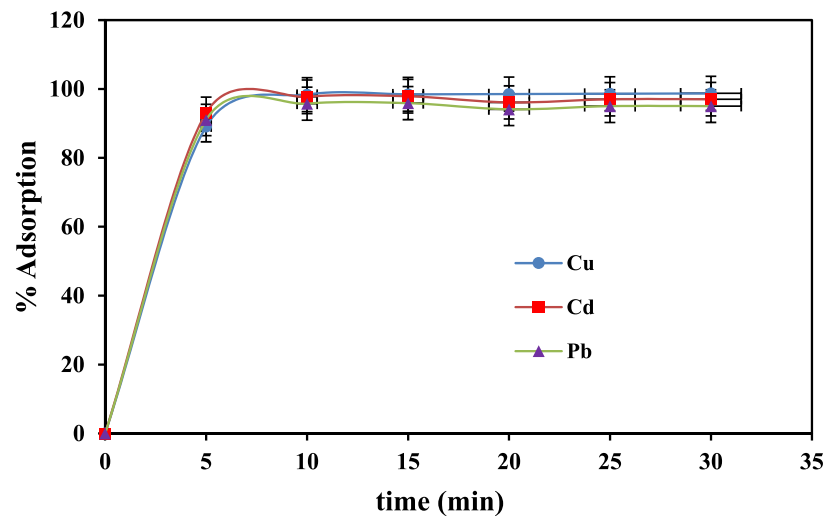

Fig. 6. Effect of contact time on the \% adsorption of $\mathrm{Cu}^{2+}, \mathrm{Cd}^{2+}$ and $\mathrm{Pb}^{2+}(10 \mathrm{~mL}$ of metal nitrate solution $1 \times 10^{-4} \mathrm{~mol} / \mathrm{L}, 25 \mathrm{mg}$ of FCMS resin, $\mathrm{pH} 7$ at $25^{\circ} \mathrm{C}$ ).
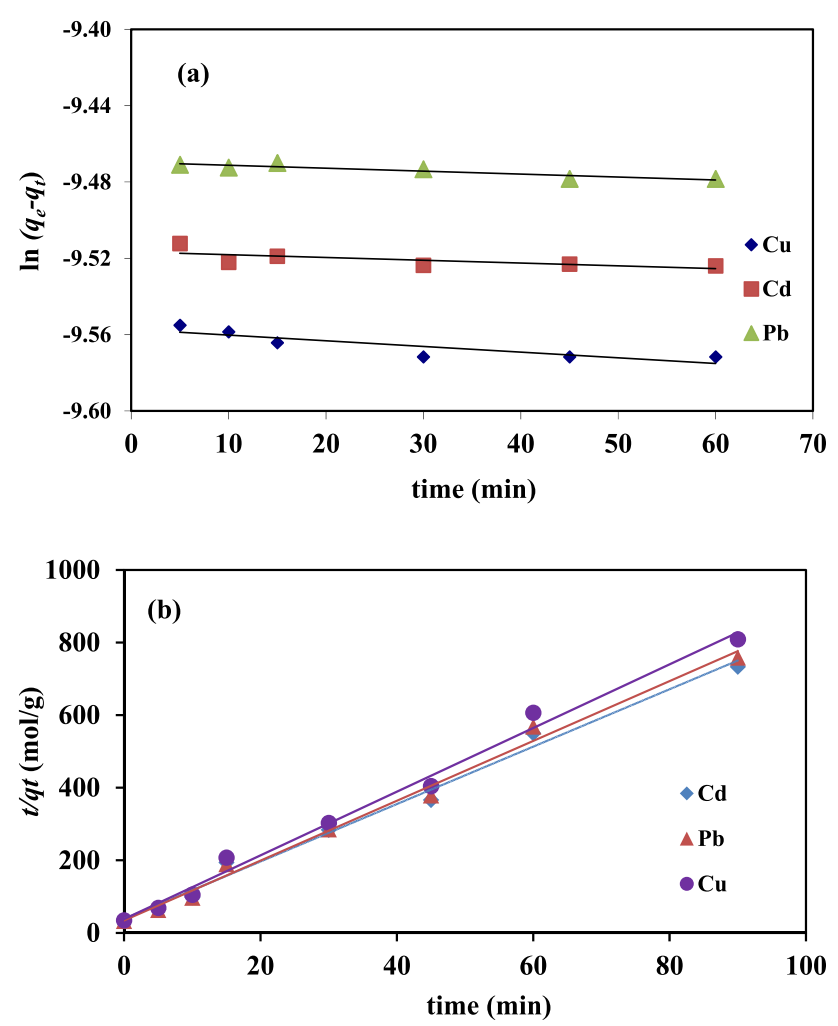

Fig. 7. (a) The graph of pseudo 1st order kinetic model (b) pseudo 2nd order kinetic model.

\subsection{Adsorption isotherm modeling}

The effect of the concentration of metal nitrate solutions in the range from $1 \times 10^{-4}$ to $1 \times 10^{-8} \mathrm{~mol} / \mathrm{L}$ on the adsorption has been presented in Fig. S4. It is clear from Fig. S4 that the adsorption capacity for metal ions increased with the increase of the concentration until the complete saturation of binding sites of FCMS resin is reached. Furthermore, equilibrium data have been validated towards different adsorption isotherm models such as Langmuir, Freundlich, and Dubinin-Radushkevich (D-R) isotherms. The Langmuir isotherm describes the monolayer formation on the surface of the resin material, and its linear form is given by Eq. (5), while the Freundlich isotherm explains the phenomenon of multilayer formation, and its linear form is expressed by Eq. (6). Moreover, D-R isotherm has been applied to demonstrate the adsorption mechanism and adsorption nature. The linear form of the D-R isotherm is demonstrated by Eq. (7).

$\frac{C e}{q e}=\frac{C e}{q}+\frac{1}{q K L}$

$\ln q e=\ln K F+\left(\frac{1}{n}\right) \ln q_{e}$

$\ln q e=\ln q_{m}-\beta \varepsilon^{2}$

where $q_{e}$ and $C_{e}$ are the adsorbed and equilibrium concentrations, respectively, $q$ is the maximum theoretical adsorption capacity $(\mathrm{mol} / \mathrm{g}), K_{L}$ is the Langmuir constant $(\mathrm{L} / \mathrm{mol}), K_{F}$ is Freundlich isotherm constant $(\mathrm{mol} / \mathrm{g}), n$ is energy or intensity of adsorption, $q_{m}$ is the theoretical isotherm saturation capacity evaluated from the $\mathrm{D}-\mathrm{R}$ isotherm ( $\mathrm{mol} / \mathrm{g}), \beta$ is the $\mathrm{D}-\mathrm{R}$ isotherm constant corresponding to the mean free energy of adsorption $\left(\mathrm{mol}^{2} / \mathrm{kJ}^{2}\right)$, and $\varepsilon$ is the Polanyi potential $(\mathrm{kJ} / \mathrm{mol})$. The $\mathrm{D}-\mathrm{R}$ model helps to calculate 
Table 3

Comparison of pseudo 1st order and pseudo 2nd order kinetic models for the adsorption of $\mathrm{Cu}^{2+}$, $\mathrm{Cd}^{2+}$, and $\mathrm{Pb}^{2+}$ metal ions by the $\mathrm{FCMS}$ resin.

\begin{tabular}{|c|c|c|c|c|c|c|}
\hline \multirow[t]{2}{*}{ Metal Ions } & \multicolumn{3}{|c|}{ Pseudo 1st order kinetic model } & \multicolumn{3}{|c|}{ Pseudo 2nd order kinetic model } \\
\hline & $K_{1} \min ^{-1}$ & $q_{e} \mathrm{mmol} / \mathrm{g}$ & $R^{2}$ & $K_{2} \mathrm{~g} / \mathrm{mol} \cdot \mathrm{min}$ & $q_{e} \mathrm{mmol} / \mathrm{g}$ & $R^{2}$ \\
\hline $\mathrm{Cu}^{2+}$ & 0.0003 & 0.07068 & 0.796 & 2.34 & 21.87 & 0.998 \\
\hline $\mathrm{Cd}^{2+}$ & 0.0001 & 0.07361 & 0.699 & 1.61 & 15.99 & 0.999 \\
\hline $\mathrm{Pb}^{2+}$ & 0.0002 & 0.07717 & 0.851 & 1.97 & 14.71 & 0.994 \\
\hline
\end{tabular}

the energy and nature of adsorption reaction using Eq. (7). The Polanyi potential $(\varepsilon)$ and the mean adsorption energy, $E(\mathrm{~kJ} / \mathrm{mol})$ can be calculated using Eqs. (8) and (9), respectively.

$\varepsilon=R T \ln \left(1+\frac{1}{C_{e}}\right)$

$E=\frac{1}{\sqrt{-2 \beta}}$

Where $\mathrm{R}$ and $\mathrm{T}$ are the universal gas constant $(8.314 \mathrm{~J} / \mathrm{mol} \mathrm{K})$ and the absolute temperature $(\mathrm{K})$, respectively.

Utilizing Eq. (5), the experimental data have been plotted between $C_{e} / q_{e}$ and $C_{e}$ as shown in Fig. S5, the values of $q$ and $K_{L}$ were obtained from the slope and the intercept, respectively, and presented in Table 4 . In addition, $R_{L}$ is a dimensionless constant and an essential parameter of the Langmuir model, which can be determined using Eq. (10).

$R_{L}=\frac{1}{\left(1+K L C_{i}\right)}$

The values of $R_{\mathrm{L}}$ indicate if the model is irreversible, favourable, linear, or unfavourable. If the value of $R_{\mathrm{L}}$ is zero, between zero and one, one, and greater than one, then the adsorption is irreversible, favourable, linear or equilibrium, and unfavourable, respectively. The values of $R_{\mathrm{L}}$ are also shown in Table 4 .

Freundlich model is validated to adsorption-phenomenon taking place onto heterogonous surfaces. This model defines the surface heterogeneity and the exponential distribution of active sites and their energies. The Freundlich model was applied using Eq. (6), straight lines with very high coefficients of determination values $\left(R^{2}>0.99\right)$ was obtained as depicted in Fig. S6) which demonstrates the validity of heterogeneous surface formation. The values of $K_{F}$ and $n$ are displayed in Table 5 .

In Freundlich isotherm, the value of $n$ is very important to understand the adsorption process. If the value of $1 / n$ is above one, then this indicates cooperative adsorption. On the other hand, if the value of $1 / n$ is between zero and one, then the adsorption is a chemisorption process, which becomes more heterogeneous as the value of $1 / n$ approaches zero $[49,50]$. In the present study, the value of $1 / n$ is between zero and one for the three investigated metal ions as displayed in Table 5. This suggests the chemisorption nature of the reaction. Comparing the results shown in Tables 5 and 6 , the values of $\left(R^{2}\right)$ for Freundlich isotherm were higher than those of the Langmuir isotherm. This indicated that the adsorption of $\mathrm{Cu}^{2+}, \mathrm{Cd}^{2+}$, and $\mathrm{Pb}^{2+}$ follows the Freundlich model quite well.

The adsorption data were also fitted to D-R isotherm by plotting $\ln q_{e}$ versus $\varepsilon^{2}$ as shown in Fig. S7. The isotherm constants $q_{m}$ and $\beta$ were determined from the slope and intercept of Fig. S7 and presented in Table 6. Analysing the values of the constants of the D$\mathrm{R}$ model revealed that the monolayer adsorption capacity values, $q_{m}(\mathrm{~mol} / \mathrm{g})$ were promising for $\mathrm{Cu}^{2+}, \mathrm{Cd}^{2+}$, and $\mathrm{Pb}^{2+}$ on the FCMS resin. Moreover, the values of $E(\mathrm{~kJ} / \mathrm{mol})$ were in the typical range of the e of bonding energy for the ion exchange mechanism (8 $16 \mathrm{~kJ} / \mathrm{mol}$ ) [51]. This suggests that an ion-exchange mechanism is involved on the surface of the FCMS resin and the adsorption process for $\mathrm{Cu}^{2+}, \mathrm{Cd}^{2+}$, and $\mathrm{Pb}^{2+}$ is controlled by physisorption.

The typical range of energy for an ion-exchange mechanism is 8-16 kJ mol - 1 [21], indicating that the adsorption of these metal ions onto resin site is mainly controlled by physical adsorption.

\subsection{Thermodynamic modeling}

Adsorption experiments of metal ions were performed at temperatures between 25 and $60{ }^{\circ} \mathrm{C}$ and presented in Fig. S8. It is clear from the figure that as the temperature increases the adsorption of metal ions increases. Furthermore, the experimental data were modelled thermodynamically using Eqs. (11) and (12) to determine the standard thermodynamic parameters, namely, the adsorption enthalpy, $\Delta H(\mathrm{~kJ} / \mathrm{mol})$, entropy, $\Delta S(\mathrm{~kJ} / \mathrm{mol} . \mathrm{K})$ and Gibbs free energy, $\Delta G(\mathrm{~kJ} / \mathrm{mol})$.

$\ln k_{c}=\frac{-\Delta H}{R T}+\frac{\Delta S}{R}$

$\Delta G=-R T \ln k_{c}$

where $k_{c}$ is the equilibrium distribution coefficient. The values of thermodynamic parameters have been evaluated from the plot of $\ln K_{d}$ versus $1 / T$ as demonstrated in Fig. 8 and given in Table 7. The $(\Delta H)$ values indicate that the adsorption process of $\mathrm{Cu} 2+$, $\mathrm{Cd} 2+$, and $\mathrm{Pb} 2+$ on the FCMS resin is endothermic, while the $(-\Delta$

Table 4

Langmuir model parameters for the adsorption of $\mathrm{Cu}^{2+}, \mathrm{Cd}^{2+}$, and $\mathrm{Pb}^{2+}$ metal ions from water. The reported data are the average of three duplicates.

\begin{tabular}{|c|c|c|c|c|c|}
\hline \multirow[t]{2}{*}{ Metal ions } & \multirow[t]{2}{*}{ Parameter } & \multicolumn{4}{|l|}{$T\left({ }^{\circ} \mathrm{C}\right)$} \\
\hline & & $25 \pm 1^{\circ} \mathrm{C}$ & $30 \pm 1{ }^{\circ} \mathrm{C}$ & $35 \pm 1{ }^{\circ} \mathrm{C}$ & $40 \pm 1^{\circ} \mathrm{C}$ \\
\hline \multirow[t]{4}{*}{$\mathrm{Cu}^{2+}$} & $q(\mathrm{~mol} / \mathrm{g})$ & $0.04162 \pm 0.012$ & $0.0467 \pm 0.011$ & $0.0470 \pm 0.011$ & $0.0471 \pm 0.011$ \\
\hline & $K_{L}(\mathrm{~L} / \mathrm{mg})$ & $9.012 \pm 0.055$ & $10.117 \pm 0.049$ & $11.816 \pm 0.042$ & $12.307 \pm 0.041$ \\
\hline & $R_{L}$ & $0.768-0.990$ & $0.89-0.990$ & $0.967-0.991$ & $0.887-0.992$ \\
\hline & $R^{2}$ & 0.789 & 0.765 & 0.719 & 0.778 \\
\hline \multirow[t]{4}{*}{$\mathrm{Cd}^{2+}$} & $q(\mathrm{~mol} / \mathrm{g})$ & $0.0389 \pm 0.013$ & $0.0391 \pm 0.013$ & $0.0401 \pm 0.012$ & $0.0410 \pm 0.012$ \\
\hline & $K_{L}(\mathrm{~L} / \mathrm{mg})$ & $11.980 \pm 0.042$ & $12.036 \pm 0.042$ & $13.440 \pm 0.037$ & $13.910 \pm 0.036$ \\
\hline & $R_{L}$ & $0.868-0.99$ & $0.789-0.99$ & $0.667-0.99$ & $0.987-0.99$ \\
\hline & $R^{2}$ & 0.699 & 0.779 & 0.793 & 0.719 \\
\hline \multirow[t]{4}{*}{$\mathrm{Pb}^{2+}$} & $q(\mathrm{~mol} / \mathrm{g})$ & $0.0138 \pm 0.036$ & $0.0199 \pm 0.025$ & $0.0207 \pm 0.024$ & $0.0299 \pm 0.017$ \\
\hline & $K_{L}(\mathrm{~L} / \mathrm{mg})$ & $8.918 \pm 0.056$ & $9.046 \pm 0.055$ & $9.681 \pm 0.052$ & $10.235 \pm 0.049$ \\
\hline & $\boldsymbol{R}_{\mathrm{L}}$ & $0.918-0.991$ & $0.877-0.997$ & $0.927-0.995$ & $0.517-0.991$ \\
\hline & $R^{2}$ & 0.799 & 0.795 & 0.788 & 0.736 \\
\hline
\end{tabular}


Table 5

Fruendlich model parameters for the adsorption of $\mathrm{Cu}^{2+}, \mathrm{Cd}^{2+}$, and $\mathrm{Pb}^{2+}$ metal ions from water.

\begin{tabular}{|c|c|c|c|c|c|}
\hline \multirow[t]{2}{*}{ Metal ions } & \multirow[t]{2}{*}{ Parameter } & \multicolumn{4}{|l|}{$T\left({ }^{\circ} \mathrm{C}\right)$} \\
\hline & & $25 \pm 1^{\circ} \mathrm{C}$ & $30 \pm 1^{\circ} \mathrm{C}$ & $35 \pm 1^{\circ} \mathrm{C}$ & $40 \pm 1^{\circ} \mathrm{C}$ \\
\hline \multirow[t]{3}{*}{$\mathrm{Cu}^{2+}$} & $K_{F}(\mathrm{mg} / \mathrm{g})$ & $2.3877 \pm 0.020$ & $2.7714 \pm 0.018$ & $2.3087 \pm 0.021$ & $2.1141 \pm 0.023$ \\
\hline & $n$ & $1.4528 \pm 0.034$ & $1.4402 \pm 0.034$ & $1.3538 \pm 0.036$ & $1.0991 \pm 0.045$ \\
\hline & $R^{2}$ & 0.995 & 0.994 & 0.997 & 0.991 \\
\hline \multirow[t]{3}{*}{$\mathrm{Cd}^{2+}$} & $K_{F}(\mathrm{mg} / \mathrm{g})$ & $1.2810 \pm 0.039$ & $1.0758 \pm 0.046$ & $1.0439 \pm 0.047$ & $1.0271 \pm 0.048$ \\
\hline & $n$ & $1.5913 \pm 0.031$ & $1.9471 \pm 0.025$ & $1.3811 \pm 0.036$ & $1.883 \pm 0.026$ \\
\hline & $R^{2}$ & 0.991 & 0.997 & 0.994 & 0.998 \\
\hline \multirow[t]{3}{*}{$\mathbf{P b}^{2+}$} & $K_{F}(\mathrm{mg} / \mathrm{g})$ & $3.4958 \pm 0.015$ & $3.4825 \pm 0.014$ & $3.0264 \pm 0.017$ & $3.0034 \pm 0.016$ \\
\hline & $n$ & $1.4480 \pm 0.035$ & $1.5451 \pm 0.032$ & $1.7617 \pm 0.028$ & $1.4601 \pm 0.034$ \\
\hline & $R^{2}$ & 0.994 & 0.993 & 0.991 & 0.995 \\
\hline
\end{tabular}

Table 6

D-R adsorption isotherm parameters for the adsorption of $\mathrm{Cu}^{2+}, \mathrm{Cd}^{2+}$, and $\mathrm{Pb}^{2+}$ metal ions from water.

\begin{tabular}{|c|c|c|c|c|c|}
\hline \multirow[t]{2}{*}{ Metal ions } & \multirow[t]{2}{*}{ Parameter } & \multicolumn{4}{|l|}{$T\left({ }^{\circ} \mathrm{C}\right)$} \\
\hline & & $25 \pm 1{ }^{\circ} \mathrm{C}$ & $30 \pm 1^{\circ} \mathrm{C}$ & $35 \pm 1{ }^{\circ} \mathrm{C}$ & $40 \pm 1^{\circ} \mathrm{C}$ \\
\hline \multirow[t]{3}{*}{$\mathrm{Cu}^{2+}$} & $q_{m}(\mathrm{~mol} / \mathrm{g})$ & $14.750 \pm 0.034$ & $14.87 \pm 0.034$ & $14.90 \pm 0.034$ & $14.98 \pm 0.033$ \\
\hline & $E(\mathbf{k} / / \mathrm{mol})$ & $11.26 \pm 0.044$ & $11.37 \pm 0.044$ & $11.61 \pm 0.043$ & $11.89 \pm 0.042$ \\
\hline & $R^{2}$ & 0.995 & 0.998 & 0.994 & 0.997 \\
\hline \multirow[t]{3}{*}{$\mathrm{Cd}^{2+}$} & $q_{m}(\mathrm{~mol} / \mathrm{g})$ & $11.51 \pm 0.043$ & $11.71 \pm 0.043$ & $11.78 \pm 0.042$ & $11.91 \pm 0.042$ \\
\hline & $E(\mathbf{k J} / \mathrm{mol})$ & $11.97 \pm 0.042$ & $12.47 \pm 0.040$ & $12.63 \pm 0.040$ & $12.89 \pm 0.039$ \\
\hline & $R^{2}$ & 0.996 & 0.997 & 0.995 & 0.991 \\
\hline \multirow[t]{3}{*}{$\mathbf{P b}^{2+}$} & $q_{m}(\mathrm{~mol} / \mathrm{g})$ & $14.62 \pm 0.034$ & $14.71 \pm 0.034$ & $14.88 \pm 0.034$ & $14.91 \pm 0.034$ \\
\hline & $E(\mathbf{k J} / \mathbf{m o l})$ & $10.95 \pm 0.046$ & $11.08 \pm 0.045$ & $11.21 \pm 0.045$ & $11.30 \pm 0.044$ \\
\hline & $R^{2}$ & 0.990 & 0.993 & 0.996 & 0.991 \\
\hline
\end{tabular}

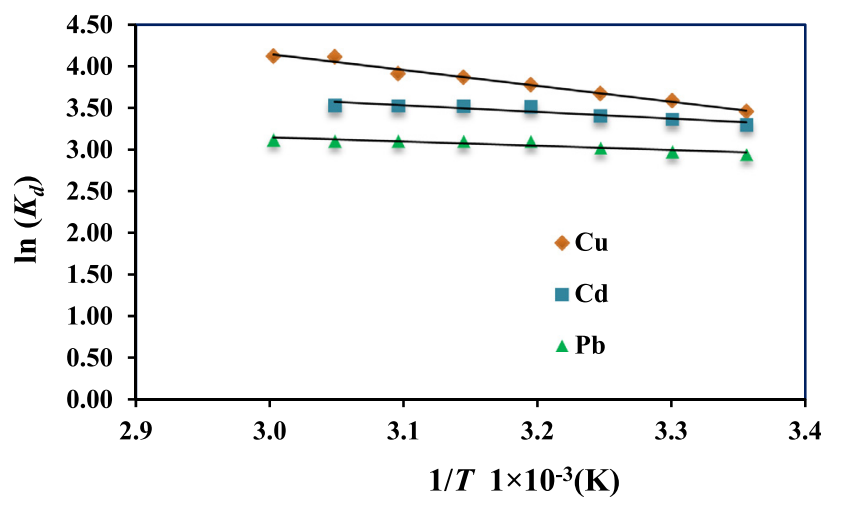

Fig. 8. Linear dependence of $\ln K_{d}$ on $1 / T$ based on the adsorption thermodynamic.

$G)$ values suggest that the adsorption process is spontaneous. It is also evident from the low values of $(\Delta S)$ that there is a reasonable affinity of the investigated metal ions towards FCMS resin.

\subsection{Adsorption in mixed solutions}

In real wastewater, there could be many other metal ions. Hence, to test the selective binding between $\mathrm{Cu}^{2+}, \mathrm{Cd}^{2+}$, and $\mathrm{Pb}^{2+}$ and FCMS resin, a mixed solution of eight metal ions was used as shown in Fig. S9. During the adsorption experiments, it was observed that the FCMS resin was selective for $\mathrm{Cu}^{2+}, \mathrm{Cd}^{2+}$, and $\mathrm{Pb}^{2+}$. Other metal ions were also under influence of soft binding sites; however, their selective binding was less than that of $\mathrm{Cu}^{2+}$, $\mathrm{Cd}^{2+}$, and $\mathrm{Pb}^{2+}$ metal ions.

\subsection{Reusability of FCMS resin}

The reusability of the FCMS resin has been examined by washing it with a dilute $0.01 \mathrm{M} \mathrm{HCl}$ solution, then neutralizing it with water, and using it again for the adsorption of respective metal ions
Table 7

Thermodynamic parameters for adsorption of $\mathrm{Cu}^{2+}, \mathrm{Cd}^{2+}$ and $\mathrm{Pb}^{2+}$.

\begin{tabular}{llllll}
\hline Metal & $\Delta H(\mathrm{~kJ} / \mathrm{mol})$ & $\Delta S(\mathrm{~kJ} / \mathrm{mol} / \mathrm{K})$ & $T\left({ }^{\circ} \mathrm{C}\right)$ & $\Delta G(\mathrm{~kJ} / \mathrm{mol})$ & $\ln \left(K_{d}\right)$ \\
\hline $\mathbf{C u}^{2+}$ & 0.01584 & 0.0820 & $25 \pm 1$ & $-8.56 \pm 0.05$ & $3.46 \pm 0.14$ \\
& & & $30 \pm 1$ & $-9.03 \pm 0.05$ & $3.59 \pm 0.13$ \\
& & & $35 \pm 1$ & $-9.40 \pm 0.05$ & $3.67 \pm 0.13$ \\
& & & $40 \pm 1$ & $-9.83 \pm 0.05$ & $3.78 \pm 0.13$ \\
& & & $50 \pm 1$ & $-10.22 \pm 0.04$ & $3.87 \pm 0.12$ \\
& & & $-10.50 \pm 0.04$ & $3.91 \pm 0.12$ \\
$\mathbf{C d}^{2+}$ & 0.0066 & & $55 \pm 1$ & $-11.21 \pm 0.04$ & $4.12 \pm 0.12$ \\
& & & $60 \pm 1$ & $-11.40 \pm 0.04$ & $4.12 \pm 0.12$ \\
& & & $30 \pm 1$ & $-8.18 \pm 0.06$ & $3.30 \pm 0.15$ \\
& & $35 \pm 1$ & $-8.47 \pm 0.06$ & $3.37 \pm 0.15$ \\
& & $40 \pm 1$ & $-9.72 \pm 0.06$ & $3.41 \pm 0.15$ \\
& & $45 \pm 1$ & $-9.32 \pm 0.05$ & $3.52 \pm 0.14$ \\
& & $50 \pm 1$ & $-9.47 \pm 0.05$ & $3.53 \pm 0.14$ \\
$\mathbf{P b}^{2+}$ & 0.0041 & $55 \pm 1$ & $-9.62 \pm 0.05$ & $3.53 \pm 0.14$ \\
& & & $60 \pm 1$ & $-9.81 \pm 0.05$ & $3.55 \pm 0.14$ \\
& & & $25 \pm 1$ & $-7.30 \pm 0.07$ & $2.95 \pm 0.17$ \\
& & $30 \pm 1$ & $-7.51 \pm 0.07$ & $2.98 \pm 0.17$ \\
& & $35 \pm 1$ & $-7.74 \pm 0.06$ & $3.03 \pm 0.17$ \\
& & $40 \pm 1$ & $-8.07 \pm 0.06$ & $3.10 \pm 0.16$ \\
& & $45 \pm 1$ & $-8.21 \pm 0.06$ & $3.11 \pm 0.16$ \\
& & $50 \pm 1$ & $-8.34 \pm 0.06$ & $3.11 \pm 0.16$ \\
& & $55 \pm 1$ & $-8.47 \pm 0.06$ & $3.11 \pm 0.16$ \\
& & $60 \pm 1$ & $-8.64 \pm 0.06$ & $3.13 \pm 0.16$ \\
\hline
\end{tabular}

as shown in Fig. 9. It is clearly seen that after 13 successive cycles a very slight difference was observed in the adsorption percentage of the FCMS resin. This slight difference may be due to the loss of some amount of material during the washing process.

\subsection{Wastewater Sample analysis}

The adsorption performance of the FCMS resin was also investigated in real wastewater. A set of water samples contaminated with metal ions were obtained from the industrial zone in Karachi, Sindh, Pakistan. A $25 \mathrm{mg}$ of the FCMS resin was added to $10 \mathrm{~mL}$ of the contaminated water as described previously in batch experi- 


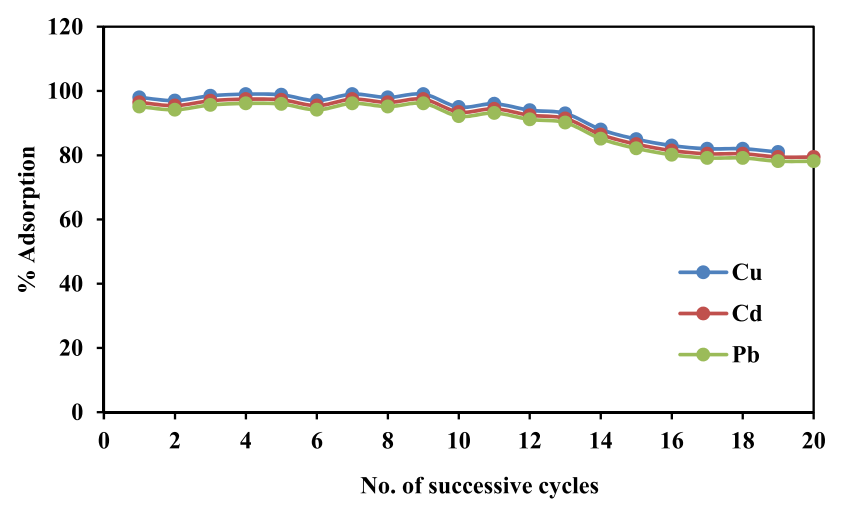

Fig. 9. The reusability of the FCMS resin.

Table 8

The comparison of FCMS resin with other adsorbent.

\begin{tabular}{llll}
\hline Adsorbent & Metal ions & $\begin{array}{l}\% \\
\text { Adsorption }\end{array}$ & Reference \\
\hline $\begin{array}{c}\text { p-tetrathioureacalix[4] arenebased } \\
\text { Merrifield resin }\end{array}$ & $\mathrm{Pb}^{2+}$ & $\begin{array}{l}92 \%(84.80 \\
(\mathrm{mmol}))\end{array}$ & {$[52]$} \\
$\begin{array}{c}\text { Nitroso-R salt impregnated } \\
\text { magnetic Ambersorb 563 }\end{array}$ & $\mathrm{Cd}^{2+} \mathrm{Pb}^{2+} \mathrm{Cu}^{2+}$ & $98 \%$ & {$[53]$} \\
$\begin{array}{c}\text { Mesoporous silica-supported bis } \\
\text { (diazo-azomethine) compounds }\end{array}$ & $\mathrm{Pb}^{2+} \mathrm{Cu}^{2+}$ & $95-99 \%$ & {$[54]$} \\
$\begin{array}{l}\text { Mucor pusillus immobilized } \\
\text { Amberlite XAD-4 bio } \\
\quad \text { composites }\end{array}$ & $\mathrm{Pb}^{2+} \mathrm{Cu}^{2+}$ & $96-97 \%$ & {$[55]$} \\
$\begin{array}{l}\text { Zeolite-based geo polymer } \\
\text { FCMS resin }\end{array}$ & $\mathrm{Cd}^{2+}$ & $98 \%$ & {$[56]$} \\
& $\mathrm{Cu}^{2+} \mathrm{Cd}^{2+} \mathrm{Pb}^{2+}$ & $98.98 \%$ & $\begin{array}{l}\text { This } \\
\text { study }\end{array}$ \\
& & $98.34 \%$ & $97.92 \%$ \\
\hline
\end{tabular}

ments. The remaining concentrations after the adsorption were analysed and exhibited in Table S3. The results revealed that the FCMS resin is effective for the remediation of wastewater contaminated with metal ions.

\subsection{Comparative study}

The adsorption efficiency of the FCMS resin was also compared to neuromas adsorbents reported in the literature used for the removal of $\mathrm{Cu}^{2+}, \mathrm{Cd}^{2+}$, and $\mathrm{Pb}^{2+}$ as demonstrated in Table 8. It is evident from Table 8 that the FCMS resin has adsorption efficiencies for the removal of the investigated metal ions comparable to other adsorbents materials.

\section{Conclusions}

This study demonstrated the adsorption of metal ions under optimized conditions using FCMS resin. The FCMS resin was characterized by FTIR, CHNS, BET, SEM, and TGA techniques. During the adsorption experiment, it was observed that FCMS resin has a good ability to bind with $\mathrm{Cu}^{2+}, \mathrm{Cd}^{2+}$, and $\mathrm{Pb}^{2+}$ metal ions under the optimized parameters of $\mathrm{pH}$, dosage, time, and temperature. The effect of time on adsorption was validated by applying pseudo 1 st order and pseudo 2nd kinetic models. Results showed that the pseudo 2nd order model is the best fit with quite high coefficients of determination values $\left(R^{2}>0.99\right)$. Moreover, the equilibrium data were well described by the Freundlich model with very high coefficients of determination values $\left(R^{2}>0.99\right)$ suggesting the multilayer formation onto the FCMS resin surface. However, the mean free energy of sorption from the D-R isotherm was between 8 and $16 \mathrm{~kJ} / \mathrm{mol}$ for the three investigated metal ions suggesting that the ion exchange mechanism is involved on the surface of the FCMS resin and the adsorption process is controlled by physisorption. The standard thermodynamic parameters such as $\Delta H, \Delta S$, and $\Delta G$ demonstrated that the adsorption is endothermic, spontaneous, with a reasonable affinity. The reusability, real wastewater experiments, and comparative studies proved that the FCMS resin is a cheaper and highly efficient material for the remediation of metal ions from contaminated water.

\section{Declaration of Competing Interest}

The authors declare that they have no known competing financial interests or personal relationships that could have appeared to influence the work reported in this paper.

\section{Appendix A. Supplementary material}

Supplementary data to this article can be found online at https://doi.org/10.1016/j.molliq.2021.116741.

\section{References}

[1] H. Zhao, X.-K. Ouyang, L.-Y. Yang, Adsorption of lead ions from aqueous solutions by porous cellulose nanofiber-sodium alginate hydrogel beads, J. Mol. Liq. 324 (2021) 115122.

[2] M. Claros, J. Kuta, O. El-Dahshan, J. Michalička, Y.P. Jimenez, S. Vallejos, Hydrothermally synthesized $\mathrm{MnO} 2$ nanowires and their application in Lead (II) and Copper (II) batch adsorption, J. Mol. Liq. 325 (2021) 115203.

[3] A.J. Sisi, M. Fathinia, A. Khataee, Y. Orooji, Systematic activation of potassium peroxydisulfate with ZIF-8 via sono-assisted catalytic process: mechanism and ecotoxicological analysis, J. Mol. Liq. 308 (2020) 113018.

[4] H. Karimi-Maleh, A. Ayati, R. Davoodi, B. Tanhaei, F. Karimi, S. Malekmohammadi, Y. Orooji, L. Fu, M. Sillanpää, Recent advances in using of chitosan-based adsorbents for removal of pharmaceutical contaminants: A review, J. Cleaner Prod. 291 (2021) 125880.

[5] H. Karimi-Maleh, S. Ranjbari, B. Tanhaei, A. Ayati, Y. Orooji, M. Alizadeh, F. Karimi, S. Salmanpour, J. Rouhi, M. Sillanpää, Novel 1-butyl-3methylimidazolium bromide impregnated chitosan hydrogel beads nanostructure as an efficient nanobio-adsorbent for cationic dye removal: Kinetic study, Environ. Res. 195 (2021) 110809.

[6] H. Karimi-Maleh, M. Shafieizadeh, M.A. Taher, F. Opoku, E.M. Kiarii, P.P. Govender, S. Ranjbari, M. Rezapour, Y. Orooji, The role of magnetite/graphene oxide nano-composite as a high-efficiency adsorbent for removal of phenazopyridine residues from water samples, an experimental/theoretical investigation, J. Mol. Liq. 298 (2020) 112040.

[7] H. Karimi-Maleh, Y. Orooji, A. Ayati, S. Qanbari, B. Tanhaei, F. Karimi, M. Alizadeh, J. Rouhi, L. Fu, M. Sillanpää, Recent advances in removal techniques of $\mathrm{Cr}(\mathrm{VI})$ toxic ion from aqueous solution: A comprehensive review, J. Mol. Liq. $329(2020) 115062$.

[8] X. Xu, X.-K. Ouyang, L.-Y. Yang, Adsorption of Pb (II) from aqueous solutions using crosslinked carboxylated chitosan/carboxylated nanocellulose hydrogel beads, J. Mol. Liq. 114523 (2020) 114523.

[9] W. He, Q. Yu, N. Wang, X.-K. Ouyang, Efficient adsorption of Cu (II) from aqueous solutions by acid-resistant and recyclable ethylenediamine tetraacetic acid-grafted polyvinyl alcohol/chitosan beads, J. Mol. Liq. 316 (2020) 113856.

[10] P.S. Kumar, C. Vincent, K. Kirthika, K.S. Kumar, Kinetics and equilibrium studies of $\mathrm{Pb} 2+$ in removal from aqueous solutions by use of nano-silversol-coated activated carbon, Braz. J. Chem. Eng. 27 (2) (2010) 339-346.

[11] G. Neeraj, S. Krishnan, P.S. Kumar, K.R. Shriaishvarya, V.V. Kumar, Performance study on sequestration of copper ions from contaminated water using newly synthesized high effective chitosan coated magnetic nanoparticles, J. Mol. Liq. 214 (2016) 335-346.

[12] T. Ahamad, M. Naushad, S.M. Alshehri, Fabrication of magnetic polymeric resin for the removal of toxic metals from aqueous medium: Kinetics and adsorption mechanisms, J. Water Process Eng. 36 (2020) 101284.

[13] A.T. Jan, M. Azam, K. Siddiqui, A. Ali, I. Choi, Q.M. Haq, Heavy metals and human health: mechanistic insight into toxicity and counter defense system of antioxidants, Int. J. Mol. Sci. 16 (12) (2015) 29592-29630.

[14] M. Jaishankar, T. Tseten, N. Anbalagan, B.B. Mathew, K.N. Beeregowda, Toxicity, mechanism and health effects of some heavy metals, Interdisciplinary toxicology 7 (2) (2014) 60-72.

[15] A.J. Bora, R.K. Dutta, Removal of metals ( $\mathrm{Pb}, \mathrm{Cd}, \mathrm{Cu}, \mathrm{Cr}, \mathrm{Ni}$, and $\mathrm{Co}$ ) from drinking water by oxidation-coagulation-absorption at optimized $\mathrm{pH}$, J. Water Process Eng. 31 (2019) 100839.

[16] P. Gholami, L. Dinpazhoh, A. Khataee, Y. Orooji, Sonocatalytic activity of biochar-supported $\mathrm{ZnO}$ nanorods in degradation of gemifloxacin: synergy study, effect of parameters and phytotoxicity evaluation, Ultrason. Sonochem. 55 (2019) 44-56. 
[17] S. Arefi-Oskoui, A. Khataee, M. Safarpour, Y. Orooji, V. Vatanpour, A review on the applications of ultrasonic technology in membrane bioreactors, Ultrason. Sonochem. 58 (2019) 104633.

[18] Y. Orooji, M.H. Irani-Nezhad, R. Hassandoost, A. Khataee, S.R. Pouran, S.W. Joo, Cerium doped magnetite nanoparticles for highly sensitive detection of metronidazole via chemiluminescence assay, Spectrochim. Acta Part A Mol. Biomol. Spectrosc. 234 (2020) 118272.

[19] Y. Orooji, R. Mohassel, O. Amiri, A. Sobhani, M. Salavati-Niasari, Gd2ZnMnO6/ ZnO nanocomposites: green sol-gel auto-combustion synthesis, characterization and photocatalytic degradation of different dye pollutants in water, J. Alloy. Compd. 835 (2020) 155240.

[20] C.A. Basha, K. Ramanathan, R. Rajkumar, M. Mahalakshmi, P.S. Kumar, Management of chromium plating rinsewater using electrochemical ion exchange, Ind. Eng. Chem. Res. 47 (7) (2008) 2279-2286.

[21] R. Gayathri, P. Senthil Kumar, Recovery and reuse of hexavalent chromium from aqueous solutions by a hybrid technique of electrodialysis and ion exchange, Braz. J. Chem. Eng. 27 (1) (2010) 71-78.

[22] E. Fereydoun Asl, F.S. Mohseni-Shahri, F. Moeinpour, NiFe2O4 coated sand as a nano-adsorbent for removal of $\mathrm{Pb}$ (II) from aqueous solutions, Eurasian, Chem. Commun. 1 (5) (2019) 480-493.

[23] A. Parchebaf, G. Nojameh, Modified nano- $\gamma$-alumina with 2, 4- dinitrophenyl hydrazine as an efficient adsorbent for the removal of Everzol Red 3BS dye from aqueous solutions, Eurasian Chem. Commun. 2 (4) (2020) 475-490.

[24] M. Sadani, T. Rasolevandi, H. Azarpira, A.H. Mahvi, M. Ghaderpoori, S.M. Mohseni, A. Atamaleki, Arsenic selective adsorption using a nanomagnetic ion imprinted polymer: Optimization, equilibrium, and regeneration studies, J. Mol. Liq. 317 (2020) 114246.

[25] K. Nithya, A. Sathish, P.S. Kumar, T. Ramachandran, Fast kinetics and high adsorption capacity of green extract capped superparamagnetic iron oxide nanoparticles for the adsorption of Ni (II) ions, J. Ind. Eng. Chem. 59 (2018) 230-241.

[26] V. Karthik, P.S. Kumar, K. Harsha Vardhan, K. Saravanan, N. Nithyakala, Adsorptive behaviour of surface tailored fungal biomass for the elimination of toxic dye from wastewater, Int. J. Environ. Anal. Chem. (2020) 1-16.

[27] R. Sivaranjanee, A. Saravanan, Carbon sphere: synthesis, characterization and elimination of toxic $\mathrm{Cr}$ (VI) ions from aquatic system, J. Ind. Eng. Chem. 60 (2018) 307-320.

[28] S. Suganya, An investigation of adsorption parameters on ZVI-AC nanocomposite in the displacement of Se (IV) ions through CCD analysis, J. Ind. Eng. Chem. 75 (2019) 211-223.

[29] A. Saravanan, P.S. Kumar, S. Karishma, D.-V.N. Vo, S. Jeevanantham, P. Yaashikaa, C.S. George, A Review on Biosynthesis of Metal Nanoparticles and its Environmental Applications, Chemosphere 128580 (2020).

[30] P.S. Kumar, A.S. Nair, A. Ramaswamy, A. Saravanan, Nano-zero valent iron impregnated cashew nut shell: a solution to heavy metal contaminated water/ wastewater, IET Nanobiotechnol. 12 (5) (2018) 591-599.

[31] F.C. Christopher, S.K. Ponnusamy, J.J. Ganesan, R. Ramamurthy, Investigating the prospects of bacterial biosurfactants for metal nanoparticle synthesis-a comprehensive review, IET Nanobiotechnol. 13 (3) (2018) 243-249.

[32] A.M. Starvin, Offline and online solid phase extraction/preconcentration of inorganics, Cochin University of Science and Technology, 2005.

[33] L.-S. Li, S.-L. Da, Y.-Q. Feng, M. Liu, Preparation and characterization of a p-tertbutyl-calix [6]-1, 4-benzocrown-4-bonded silica gel stationary phase for liquid chromatography, J. Chromatogr. A 1040 (1) (2004) 53-61.

[34] M.A. Kamboh, I.B. Solangi, S. Sherazi, S. Memon, A highly efficient calix [4] arene based resin for the removal of azo dyes, Desalination 268 (1-3) (2011) 83-89.

[35] R. Junejo, N.S. Jalbani, S. Memon, S. Kaya, S. Erkan, G.l. Serdaroĝlu, I.M. Palabiyik, Equilibrium, Thermodynamic, and Density Functional Theory Modeling Studies for the Removal of Dichromate Ions from Wastewater Using Calix [4] arene Modified Silica Resin, J. Chem. \& Eng. Data (2020).

[36] R. Junejo, S. Memon, F.N. Memon, A.A. Memon, F. Durmaz, A.A. Bhatti, A.A. Bhatti, Thermodynamic and kinetic studies for adsorption of reactive blue (RB-
19) dye using calix [4] arene-based adsorbent, J. Chem. Eng. Data 64 (8) (2019) 3407-3415.

[37] R. Junejo, N. Shams Jalbani, S. Kaya, G. Serdaroglu, S. Şimşek, S. Memon, Experimental and DFT Modeling Studies for the Adsorptive Removal of Reactive Dyes from Wastewater, Sep. Sci. Technol. (2021) 1-15.

[38] R. Junejo, S. Memon, S. Kaya, Effective Removal of the Direct Black-38 Dye from Wastewater Using a New Silica-Modified Resin: Equilibrium and Thermodynamics Modeling Studies, J. Chem. Eng. Data (2020).

[39] R. Junejo, S. Memon, I.M. Palabiyik, Efficient adsorption of heavy metal ions onto diethylamine functionalized calix [4] arene based silica resin, Eurasian Chem. Commun. 2 (7) (2020) 785-797.

[40] R. Junejo, S. Memon, F. Durmaz, A.A. Ahmed, F.N. Memon, N.S. Jalbani, S.S. Memon, A.A. Bhatti, Synthesis of Piperdinomethylcalix [4] arene Attached Silica Resin for the Removal of Metal Ions from Water: Equilibrium, Thermodynamic and Kinetic Modelling Studies, Adv. J. Chem.-Sect. A 3 (2020) 680-691.

[41] A.T. Reda, D. Zhang, Sorption of metal ions from aqueous solution by sulfonated calix [4] arene intercalated with layered double hydroxide, J. Environ. Chem. Eng. 7 (2) (2019) 103021.

[42] C.D. Gutsche, M. Iqbal, D. Stewart, Calixarenes. 19. Syntheses procedures for ptert-butylcalix [4] arene, J. Org. Chem. 51 (5) (1986) 742-745.

[43] C.D. Gutsche, L.-G. Lin, Calixarenes 12: the synthesis of functionalized calixarenes, Tetrahedron 42 (6) (1986) 1633-1640.

[44] P.K. Jal, S. Patel, B.K. Mishra, Chemical modification of silica surface by immobilization of functional groups for extractive concentration of metal ions, Talanta 62 (5) (2004) 1005-1028.

[45] M.A. Kamboh, I.B. Solangi, S. Sherazi, S. Memon, Synthesis and application of ptert-butylcalix [8] arene immobilized material for the removal of azo dyes, J. Hazard. Mater. 186 (1) (2011) 651-658.

[46] M.A. Kamboh, A.A. Bhatti, I.B. Solangi, S. Sherazi, S. Memon, Adsorption of direct black-38 azo dye on p-tert-butylcalix [6] arene immobilized material, Arabian J. Chem. 7 (1) (2014) 125-131.

[47] S. Memon, A. Ali Bhatti, N. Memon, New calix [4] arene appended amberlite XAD-4 resin with versatile perchlorate removal efficiency, J. Chem. Eng. Data 58 (10) (2013) 2819-2827.

[48] A. Al Bsoul, M. Hailat, A. Abdelhay, M. Tawalbeh, I. Jum’h, K. Bani-Melhem, Treatment of olive mill effluent by adsorption on titanium oxide nanoparticles, Sci. Total Environ. 688 (2019) 1327-1334.

[49] A. de Sá, A.S. Abreu, I. Moura, A.V. Machado, Polymeric materials for metal sorption from hydric resources, Elsevier, Water purification, 2017, pp. 289-322.

[50] A. Al Bsoul, M. Hailat, A. Abdelhay, M. Tawalbeh, A. Al-Othman, A.A. Al-Taani, Efficient removal of phenol compounds from water environment using Ziziphus leaves adsorbent, Sci. Total Environ. 761 (2021) 143229.

[51] Y. Ho, J. Porter, G. McKay, Equilibrium isotherm studies for the sorption of divalent metal ions onto peat: copper, nickel and lead single component systems, Water Air Soil Pollut. 141 (1) (2002) 1-33.

[52] A.A. Bhatti, A.A. Bhatti, I.B. Solangi, S. Memon, Pb2+ adsorption behavior of calix [4] arene based Merrifield Resin, Desalin. Water Treat. 51 (22-24) (2013) 4666-4674.

[53] M. Soylak, Z. Erbas, Vortex-assisted magnetic solid phase extraction of Cd (II), $\mathrm{Cu}$ (II) and $\mathrm{Pb}$ (II) on the Nitroso-R salt impregnated magnetic Ambersorb 563 for their separation, preconcentration and determination by FAAS, Int. J. Environ. Anal. Chem. 98 (9) (2018) 799-810.

[54] S. Uruş, M. Karabörk, H. Köksal, Synthesis, characterization and solid-phase extraction properties of novel bis (diazo-azomethine) ligands supported on mesoporous silica, Appl. Organomet. Chem. 32 (1) (2018) e4022.

[55] S. Baytak, A.M. Channa, E. Çamuroğlu, Mucor pusillus immobilized Amberlite XAD-4 biocomposites for preconcentration of heavy metal ions by solid-phase extraction method, J. Anal. Sci. Technol. 9 (1) (2018) 9.

[56] H. Javadian, F. Ghorbani, H.-A. Tayebi, S.H. Asl, Study of the adsorption of Cd (II) from aqueous solution using zeolite-based geopolymer, synthesized from coal fly ash; kinetic, isotherm and thermodynamic studies, Arabian J. Chem. 8 (6) (2015) 837-849. 